\title{
PRINCIPLES OF ENGLISH LEXICAL COMPETENCE FORMATION OF FUTURE FINANCIERS ACROSS THE INFORMATION SOCIETY CONTEXT
}

\section{Alona Panasenko ${ }^{1}$ \\ Halyna Kuznetsova ${ }^{2}$}

DOI: https://doi.org/10.30525/978-9934-588-53-2-21

\begin{abstract}
In the article, we have attempted to analyze the basic principles of English lexical competence formation for future specialists in finance, banking and insurance in the context of information development of society. The main contradictions in the theory and practice of this problem are clarified. Methodology: the theoretical level of research includes such scientific methods as analysis, synthesis, induction, deduction, and comparison; the empirical methods are observation, method of associations and analogies, and the analytical and synthetic (affirmative) survey. Documents of state importance, scientific and pedagogical, methodological literature are studied according to the rapid development of information and communication technologies in education, the widespread introduction of English in the practical financial sphere. It is proved that the principles of learning should be the basis for the standards, professional programmes creation, and the formulation of their integrated competence, the formation of general and professional competencies of future finance professionals. It is substantiated that among the special competencies, the key is English lexical competence. Among the fundamental principles of formation of English lexical competence there are the basic principle of "knowledge society" and its components: scientificity, consciousness, systematicity and consistency, visualization, continuity and perspective, connection between theory and practice, active interdisciplinary communication (coordination). The electronic services for the implementation of each principle of English
\end{abstract}

\footnotetext{
${ }^{1}$ An English Lecturer,

Hlukhiv Agrotechnical Institute named after S.A. Kovpak, Ukraine;

Postgraduate student,

Oleksandr Dovzhenko Hlukhiv National Pedagogical University, Ukraine

${ }^{2}$ Doctor of Pedagogical Sciences, Associate Professor,

Oleksandr Dovzhenko Hlukhiv National Pedagogical University, Ukraine
} 
lexical competence are identified, they are Google Presentations; Google Classroom, Zoom, Edmodo, Skype, "A Dictionary of Finance and Banking" Oxford App, WhatsApp, Viber, etc.

\section{Introduction}

The contemporary world functions in the age of digitalization, or the digital transformation of any information, and educational in particular. Global processes of digital communication through information and communication technologies have led to the access into the scientific, political, educational, philosophical meaning of the term "information society", which are defined by "digital society", "post-industrial society", "service society", "knowledge society", "network society", "network intelligence society", etc.

Globalization and digitalization of society as an information structure make it possible to outline a new way of professional development of a person in the process of obtaining a higher education under the relevant educational programmes. Nowadays, the high school of Ukraine tries to direct all economic, personal, scientific efforts to transfer educational information into the appropriate digital form through digital technologies (this process is called "digitization"). In this way, one of the leading competencies that a specialist has to master in a certain area of knowledge in the key system, is digital literacy, which is the beginning to dominate among the required social skills.

However, it is important to remember that any digitized information will not exist without the language. Today, the English language holds the leading position in the world linguistic, communicative and informative space, acquires a "technological status" (according to V.A. Shyrokov). It is a rotator of the international communication language, and especially in the information-technological and economic spheres of human activity. In the view of this, we consider that the preparation of highly qualified English-speaking specialists in the economic and financial sphere based on information and communication technologies is an extra meaningful task for the progressive development of the financial and economic education in Ukraine. Such statements places a great responsibility on higher educational establishments and higher professional education as the main base for the training of innovative and qualified professionals, motivated and able to further self-development in the era of social digitalization. 
The English acquisition in the system of bilingual education by future financiers is prompted by the fact that a significant amount of literature in international economic, financial direction, banking is concluded in English. In order to master this vocabulary, the future specialist must, firstly, learn the lexical professionally oriented language systems of both native and English. Therefore, it is worth agreeing with M.O. Vakulenko's opinion that "the study of professional vocabulary is an important scientific and technical problem, the successful resolution of which depends on the effectiveness of international contacts of the state and its place in the world division of labor" [3, p. 10].

Thus, our first scientific goal is to determine a concept of English lexical competence of future specialists in finance, banking and insurance based on information development of society, especially where the principle of "knowledge society" dominates, emphases on the education functions, which leads to the acquisition of key competences, the ability to life learning education. Furthermore, the second task is discussing the derivative principles in the structure of the dominant "knowledge society", which are the basis for the methodology of formation English-speaking lexical competence of future financiers by means information and communication technologies (ICT).

The analysis of the literature shows that I. A. Yarema, I. Ye. Potiuk, M. O. Kniazian defined the essence of the concept "English-speaking competence" in various aspects. Some scholars devoted the papers to the study of English vocabulary (Bankevych L.V, Bukhbinder V.A, Nikolaieva S. Yu., Smolina S.V., Shchukin A.N. and others).

A number of detailed researches are devoted to the methodology of intercultural foreign language competence formation (Bakum Z. P., Bihych O. B., Borysko N. F., Havryliuk N. M., Hryshaieva L. I., Hrushevitska T. G. and others).

L. M. Koval, R. Yu. Martynova, N. V. Siaska, S. V. Shermazanova and others traced problems of English lexical competence formation in students of non-philological profile.

The general basics of English acquisition on the principles of introduction the information and communication technologies are reflected in the scientific papers by S.V. Bodnar, I.H. Kostenko, I. S. Zaiarna, I. B. Karpa, Z. P. Ovcharenko and others. 
V. V. Bebih, I. I. Shostak covers the methodological aspect of the research problem in their dissertation partially, which helps to foresee the improvement of content, methods, different forms as well as active educational activity forms for students, future specialists of the financial sphere.

However, we have not fully substantiated the fundamental principles of formation of English lexical competence of future bachelor of finance in the global digitalization era of human activity in the last findings.

In addition, we noticed some contradictions in the theory and practice of forming English lexical competence of future specialists in the financial industry in the context of information development of society, which need special attention and gradual resolution at the social, scientific, theoretical and methodological levels:

- the social-information requirements for the identity of future specialists in financial, banking and insurance do not fully correspond to the real level of their preparation;

- the social order for an English-speaking person in the professional financial sphere denies the reproductive content of their training, which now dominates in the high educational establishments;

- students' perceived necessity to solve practical problems in the financial sphere with a support of information and communication technologies and mastery of an advanced level of English professionally-oriented lexical competence is not evidenced by the development of these abilities.

Outlined contradictions have actualized the problem of the study essentially, imperative to design its initial provisions, "which together determine the requirements for the educational process as a whole and its constituents (goals, objectives, methods, tools, forms) in particular" [7, p. 110; 13, p. 147]. Mainly the initial statements of mastering a particular specialty are the basis for the establishment of state educational standards, formulation of the integrated competence of educational programmes.

\section{Requirements to the formation}

\section{of English lexical competence bachelors in finance}

The aims and content of the various educational programmes of speciality 072 "Finance, Banking and Insurance" in the Ukrainian high schools should take into account the requirements of the current financial 
domestic and international labour markets, the nature and importance of conducting effective financial activity, it is dependent on the laws of functioning and development of financial systems in different countries. Given that, take a possibility to indicate the key competence as the ability to communicate effectively in the state and foreign languages both orally and in writing. It was discussed in the state standard of higher education of Ukraine in the preparation of bachelors of speciality "Finance, Banking and Insurance", approved by the order of the Ministry of Education and Science of Ukraine № 729 on May 24, 2019. We paid attention on a foreignlanguage communicative competence and its lexical component.

The question of the formation of English-speaking lexical competence, and in the financial and economic sphere in particular, is not new. Many approaches, methods, methodical techniques for intensive English lexis acquisition have been developed (Akopian V. H., Aleksandrov V. M., Varenina L. P., Hehechkori L. Sh., Kytaigorodska H. O., Starchenko V. D., Tashpulatova F. S. and others), investigated the psychological basis of its study (Beliaev B. V., Zimnia I. O., Zinchenko P. I., Tereshkova O. M. and others).

It is important to note that cognitive (Bodnar S. V., Borshchovetska V. D., Mushinska N. S. and others), problematic (Brudnyi A. A., Bukatnikova S. D.), communicative (Nazarenko O. B., Passov Ye. I., Samosenkova T. V. and others) approaches to the English lexical competence formation are of interest among scientists, because deep and profound knowledge of vocabulary, and professional in particular, appropriate and correct service of it, contribute to better assimilation of professional information in oral and written speech.

The analysis of scientific, methodological sources, linguistic recommendations shows that the concept of "English lexical competence" interpreted in various ways. The Common European Framework of Reference for Languages: Learning, Teaching, Assessment set out a general definition of this concept: "knowledge of, and ability to use, the vocabulary of a language, consists of lexical elements and grammatical elements" [15, p. 110].

I. P. Makarenko explains the studied term as "the presence in the personality of a certain stock of words in the framework of professional development, the ability to use vocabulary", phrases, collocations, expressions appropriately [6, p. 11]. However, the definition does not focus on the methodological component of speech ability formation. 
N.A. Shandra interprets English lexical competence in the aspect of its formation by means of information technologies, which has been discussed with the subject of our publication. "Integrated quality of specialists, which allows them to apply a complex of knowledge, skills and abilities to use the English vocabulary in writing in the process of writing activities according to the communicative task of situations in computer science professionally oriented communication" [11, p. 262]. According to this definition, the author bypasses the oral form of speech, which, in our view, does not allow us to correct written English. This discussion might continue as each contributor tries to reflect his or her own subject and research object.

Due to our research, it is necessary to take into account the complex approaches to mastering foreign language lexical competence, the integrated focus of English communication on both key and professional competencies, as this is triggered by the challenges of the information society, the change and variation of the educational environment where knowledge is acquired and professional skills are formed. Thus, we explain lexical English competence as the ability of a specialist to use the language professionally oriented vocabulary effectively in the process of professional activity during digitization of professional information.

We note that modern globalization and integration processes have become the foundation for the development of external academic mobility of students, which can be considered as one of the means of mastering English in the English language environment by a certain professional vector. Cooperation with business schools providing intensive full-time and distant professional courses and financiers in particular recognized as relevant. However, only those educational entrants who have attained at least B2 proficiency in English in accordance with the requirements of the European Union standards may be students of such courses.

This is even more convincing in expanding the boundaries of the multilingual educational and communication environment, as well as the multifaceted nature of the information society. While the essence of its concept lies in the fact that knowledge, information and intellectual potential of a person, his/her desire to improve, to learn throughout life, are of paramount importance in the development of all social spheres. The priority of the information society, according to V. Yu. Bykov, is "comprehensive and organic human development, creation of conditions for its spiritual and 
mental enrichment, increase of national human capital as a basis for the development of political, social, economic, humanitarian, cultural and other spheres of social life, above all in the interest of improving the well-being of citizens, efficiency of economy and strengthening of statehood " [3, p. 41].

From our point of view, the information society is a people-oriented and open-ended society where everyone can create, access, share, use and exchange information, empowering individuals, communities. It helps peoples to fully realize their potential, aspirations, promote their sustainable development and improve their quality of life, creating national information resources to the extent necessary to support scientific, technological, educational, socio-historical, cultural steady progress, which is constantly accelerating. Such a society creates the conditions for the development of soft skills, which will inevitably belong to the digital literacy of future professionals as a basic requirement of a qualified professional.

Continuously more, a key and crosscutting component of the information society is a knowledge acquired through learning, depending on the challenges of society, are constantly updated and deepened in their professional activities. Rather than those are equated with awareness through the information society, through an inclusive worldwide network where, to some extent, the individual is lost, his contribution to knowledge, to the development of knowledge as a scientific achievement. This leads to the statement that the information society, which is the basis of technology and their influence on the dissemination, exchange, storage of information database, should be a component of the knowledge society, its functional part.

Studied literature (Petrushenko O.P., Melnyk O.L., Firsov V.R., Savchenko S.V. and others) shows that since the 1990s the phrase "knowledge society" has already functioned as a term. Moreover, we consider its definition multifaceted and debatable.

In our study, we use Peter Drucker's primary definition, which explains the "knowledge society" as a type of economy where knowledge plays a decisive role and their production becomes a source of development [5]. As well as we support setting out its vision for knowledge societies in UNESCO's 2005 Word Report, as “an excess of information is not necessarily the source of additional knowledge. What is more, the tools that can be used to "process" that information are not always up to the task. In knowledge societies, everyone must be able to move easily through the flow 
of information submerging us, and to develop cognitive and critical thinking skills to distinguish between "useful" and "useless" information. Useful knowledge is not simply knowledge that can be immediately turned into profit in a knowledge economy - "humanist" and "scientific" knowledge obey different information-use strategies" [17, p.19]. This statement generally specifies the role of an individual society in the general concept.

Therefore, the information society is impossible without knowledge that should be acquired, memorized, interpreted scientifically, presented ways to acquire new knowledge, to produce its own, necessary for successful professional activity, mastering new skills.

\section{Principles of learning in the "knowledge society"}

Today, the gained knowledge in the higher educational establishments is only the basis of successful studying. Besides that, each student has to develop the ability to turn this basis into a way of life. This is the principle of lifelong education. From such point of view, we note that the fundamental principle of learning and the lexical English-language competence formation of future financial professionals in particular, is the principle of "knowledge society". The analysis of the above-mentioned UNESCO report "Towards Knowledge Societies" (2005) states that "the semantic aspect of education cannot be separated from languages and knowledge" [17, p. 20].

As other principles of learning with their classifications, presented in methodological, pedagogical and linguistic sources, we consider components (hyponyms - words, the meaning of which is included in the meaning of another word) of the principle of "knowledge society", which in the system of lexical units acquires the status of hypernym (a word whose meaning includes a group of other words).

Scientists (Bobylova L.I., Halskova N.D., Semenchuk Yu.A., Tarnopolskyi O.B., Tereshchuk V.H., Shchukin A.M. and others) in the system and structure of teaching English principles, and mastery of lexical English competence, first of all, distinguish the following: scientific, consciousness, activity, interdisciplinary coordination, communication, interconnected learning, professional orientation, etc. [9;13].

In the general teaching methodology, there are general didactic and methodical principals. According to Z.P. Bakum, O.O. Palchikova, S.S. Kostiuk (2019), the principles are "basic theoretical provisions that 
provide information about the features of the learning process and ensure its effectiveness" [1, p. 89].

We single out those general didactic principles that, in our opinion, most effectively help to organize the educational process of learning a foreign language, and the formation of English lexical competence in the first place. Among them: scientificity, consciousness, systematicity and consistency, visualization, continuity and perspective, connection between theory and practice, active interdisciplinary communication (coordination) (Figure 1).

We have focused on those principles that are relevant in the information society and could implement in the system of the principle of "knowledge society". Therefore, we discuss each of them.

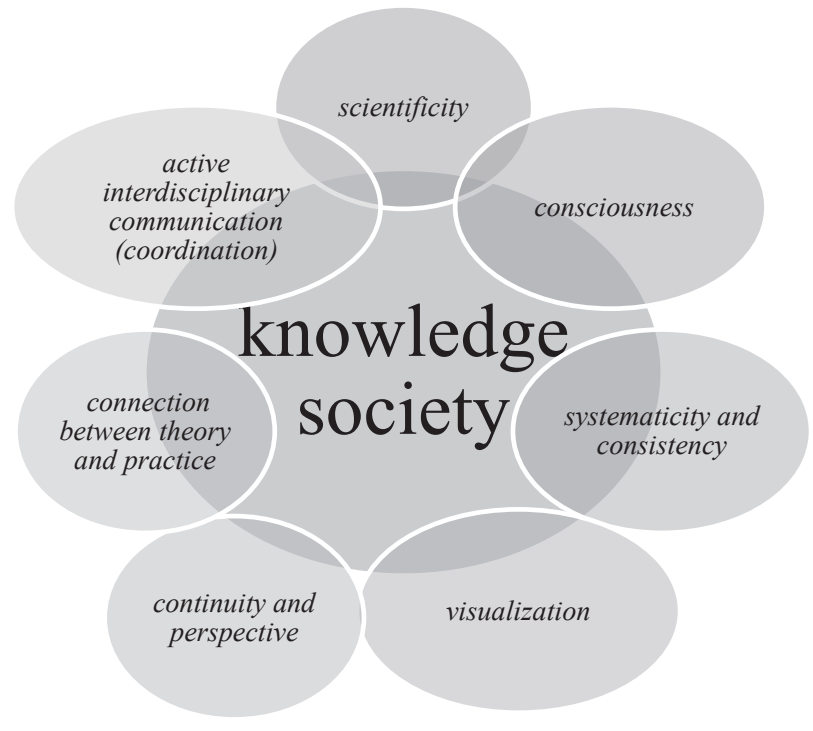

\section{Figure 1. Coordination between general didactic principles of learning in the "knowledge society"}

The principle of scientificity is one of the fundamental, as it directs the educational process to the selection of methods and techniques that takes into account modern scientific provisions of the subject, the actual component of knowledge, including features and needs of foreign language 
communication in the digital world industry. Given this, the basis for the formation of lexical competence in future financial professionals is:

- scientific facts about the etymology of professional vocabulary,

- its lexical semantics (the relationship of lexical meaning and concept, the structure of lexical meaning, its impact on the content, types of word meaning (specific, abstract, processes materialization),

- system relations of lexical units,

- processes of formation of lexical financial and economic terminology), etc.

In order to introduce named principle in the classroom future bachelors in finance have to check themselves in digital vocabularies such as:

https://www.collinsdictionary.com/dictionary/english-thesaurus

https://www.lexico.com/synonym

https://www.macmillanthesaurus.com/active

https://www.merriam-webster.com/thesaurus

https://thesaurus.yourdictionary.com

Special mobile apps are also very effective for improving vocabulary for specific purposes. We use "A Dictionary of Finance and Banking" App from Oxford. It helps to revise words any time students like. The app provides up-to-date coverage of the vocabulary used in money markets, commodity markets, banking, central banking, foreign exchanges, derivatives trading, finance control, monetary policy, local government, takeovers and merges, as well as business loans and corporate restructuring. It represents generous coverage of the terms used in public-sector borrowing and the European Union. Many new terms associated with the advent of high frequency electronic trading were added.

"Reliance on consciousness, as Z.P. Bakum notes, is especially important in the process of learning languages with a developed morphological system $\ldots, \ldots$ otherwise the learning process will turn into a mechanical memorization of several standard dialogues, which cannot be used even in a slightly changed situation» $[2$, p. 230]. This indicates that the principle of consciousness is one of the main in the system of general didactic and methodical principles.

Implemented on awareness of future financial professionals of the role and place of English in their professional development, all components of the organization and conduct of the educational process. It aims to select the appropriate language, speech material, modelling of professional realities, 
solving current professional problems, designing the trajectory of effective formation of lexical English competence of students, the ability to use professional oral and written speech independently.

Apart from it, the principle of consciousness performs a binary educational-linguistic function: it correlates the interrelation of the native language usage during the study of a foreign language, regulates the interference influence of one language on another.

The principle of consciousness affects significantly on the action of other principles:

- learning activities (speech, intellectual, emotional, empathic);

- logic and sequence, when students are aware of the place of a foreign language in the logical-structural system of disciplines, the sequence of introduction of new material, the scope of tasks, the hierarchy of formation of key professional competencies, and lexical in particular;

- availability and effective ability to master foreign language material depending on the social and professional situation, the parameters of the speech act, guidelines, advice of the teacher, control of assessment of acquired knowledge and competencies;

- strength, which is aimed at the conscious "work" of the auditory, motor, visual, speech-motor analysers, to store in memory the necessary information, its constant reconstruction.

The method of projects is a novel example of the principle of consciousness. It demands a complex of professional skills and foreign language knowledge to implement them into meta activity with aims, tasks, results. In order to realise such activity students use different ICT (Internet Browsers, Microsoft Office, Microsoft Excel, Power Point, etc).

Students aim the principle of visualization, by means of which the listener creates a linguistic picture of his own imaginary world, at the sensory perception of English-speaking lexical material. There are linguistic and non-linguistic (subject-pictorial) clarity. Linguistic visualization involves the listener's focus on the English word, its auditory, graphic, visual and articulatory image. For example, the formation of utterances in the native language involves establishing the correspondence of the language situation and a specific language combination - support. If the structure of the utterance is disturbed, the context may change. The participant feels it in the language situation clearly. 
However, such a process is observed during the learning the material of native language based on language intuition, which is essentially a previously acquired experience.

Thus, linguistic visualization is a mean of semantization, mastering the situational relevance of language. With the help of visualization, students practice different learning situations both oral monologue communication and the linguistic reaction to objective reality and life situations. Thus, visualization in teaching a foreign language for specific purposes helps to reveal the meaning of statements and models life situations where communication takes place. The principle of visualization in the foreign language teaching application takes the form of situational clarity.

Besides, subject-imaginable visualization covers various tools (keywords, diagrams, orientation questions, objects, materials, etc.) that provide lexical content of the student's statement, creating an imaginary character of a participant in a speech situation or role play (a partner, a colleague or a leader), who does a certain social role.

Lexical foreign language competence in a broad sense testifies to "a person's ability to design their statements correctly and understand the speech of others, and is based on complex and dynamic interaction of relevant skills, knowledge and lexical awareness" [10, p. 16]. It is a mandatory component of professional communicative competence, when communication is impossible without its full-fledged mastering.

The clarity of the lexical material studied and mastered in the system of lexical competence formation and facilitated by modern means of information and communication technologies (we give examples with regard to the improvement of four types of speech activity):

- listening comprehension (using Youtube for watching films, podcasts, videos before doing assignments);

- reading comprehension (reading articles or another information through the Internet browsers in order to find out main professional issues, topics, recommendations);

- speaking (developing oral communication between group mates, tutors and future employers using video conferences by Skype, Viber, Zoom, WhatsApp);

- writing (using interactive boards in order to matching words, filling gaps in sentences or texts; social networks Instagram, Facebook, Edmodo 
for posting topical blogs, email - for developing writing communication between group mates, tutors and future employers).

Hind A. Al Fadda in the scientific review "Determining How Social Media Affects Learning English: An Investigation of Mobile Applications Instagram and Snap Chat in TESOL Classroom (2020)" states that "Instagram may be a motivating and engaging means of teaching English to students who speak another native language". According Brebara's report (2018) " $88 \%$ of 152 graduate students in the Czech Republic viewed Instagram as useful in learning English. Yeh and Mitric (2019) integrated Instagram into a course, using it to help students engage in digital storytelling" [14].

The principle of visualisation is closely related to the principle of connection between theory and practice, which testifies to the level of formation of the future financial specialist's ability to formulate their own opinions, express themselves orally and in writing in a foreign language and understand, analyze what others have heard.

Traditionally, the lexical component of English-language competence has certain methodological features of formation, the basis of which is the appropriate selection of lexical foreign language material and its effective and rational use [8, p. 111-116], which involves a clear mechanism of actions, among them:

- identification of the most common communication situations of future employees in the field of financial management;

- creation of an appropriate educational environment and formulation of typical topics;

- selection of situational and thematic complexes;

- creation of language situations that contain features of future professional communication;

- selection of educational texts of professional orientation;

- selection of the language minimum of professional vocabulary in the field of finance and management;

- usage of information and communication technologies of training in the formation lexical competence, and distance in particular.

Using mobile messenger apps such as Viber or WhatsApp is one way to support the remote learning of English. There are varieties of ways that these apps can be used. These are some tips: 
a) You can have one group set up for the whole group. You can also create separate groups within the academic group, perhaps up to five students in each one according the language knowledge level. This will make the conversations easier to manage.

b) Plan and write down what you want your students to have learned by the end of the week.

c) "It is easy to share new vocabulary items. Try sharing a few words each day. You can share photos of objects or drawings to explain the words. You can record yourself saying the words and send the audio file. You can draw out diagrams or what you might show on the board in the classroom on a piece of paper. Take a photo of it and send it to the group - it might be easier to do that sometimes than writing information out as a text message" [16].

d) Share short professional news from newspapers as text or audio files. Introduce new vocabulary. Send some questions for the learners to answer about what has been already heard.

e) Set practice tasks around the textbook.

f) Receive work from students and give feedback.

The principle of systematicity and consistency aimed analysing the process of practical implementation of the method of mastering a foreign language and professional vocabulary primarily by socio-economic specialists, and allows identifying the following stages of formation English lexical competence:

I. Operational-automatic stage (semantization of lexical units, during which there is a receptive assimilation of English lexical material, perception of graphic and sound (phonemic) form of a word as lexeme, sememe, clarification of sememe).

II. Reproductive-active stage (improvement and automation of actions with new language material aimed at conscious mastering the professional content).

III. Communicative-strategic stage (determines the ways of development and further automation of speech actions of students, control over the level of formation of English lexical competence during modelling of professional communicative situations, designing ways to increase levels of lexical competence).

The purpose of every stages achieved by using a certain type of exercises that are interdependent, interconditioned and focused on the formation of lexical skills in reading, listening, speaking and writing: 
1) exercises for the formation of professionally oriented lexical skills (receptive, non-communicative, conditionally communicative);

2) exercises aimed at improving professionally oriented lexical skills (reproductive, receptive-productive, conditional-communicative, communicative);

3) exercises that involve the development of professionally oriented speech skills, the formation of English lexical competence (receptive-productive, productive, creative, conditionally communicative, communicative).

The principle of systematicity and consistency necessarily foresees the involvement in the organization of the educational process of interactive information technologies, such as:

- Interactive technologies of cooperative learning (organization selfstudy in pairs, small groups by means of Skype, Viber, WhatsApp);

- Interactive technologies of collective-group learning (implementation of CASE-method, projects' presentation through Microsoft Power Point, online program Trello);

- Technologies of situational modelling (composing situational, analogue dialogues using Skype, Viber, WhatsApp during self-study);

- Technologies for processing discussion issues (debates in English using video-chats in Skype, Zoom, Google Presentations etc.).

The principle of active interdisciplinary communication (coordination) aims the formation English lexical competence of future specialists in the financial sphere, which, according to S. Yu. Nikolaieva, "contributes to the creation of conditions for the formation of professionally oriented communicative competence within the chosen study profile" [7, p. 114].

The fundamental issue of the formation of English lexical professionally oriented competence is implementation of the effect of "professional language and speech immersion" based on productive bilingual learning. It means serving two languages (Ukrainian and English) "within the same language group that uses these languages in the relevant communicative areas, depending on the social situation and other parameters of communicative act" [12, p. 115] in the future occupation through the coordinated creation of a professionally oriented environment. This statement is the logical relationship of educational components in the area of professional training programme curriculum and purposeful interpersonal communication of students, teachers, stakeholders, employers. 
Educational information tools undoubtedly have a significant impact on the degree of its formation. For example, in the classroom we used different presentations made by means of the Microsoft Power Point program in order to combine English learning acquisition and the most important finance and banking topics ("Financial statements: cash flows, balance sheets, profit and loss", "Auditing and debt recovery", "Corporate finance", "Companies' financial strategies", "Accounting standards and tools. Financial ratios", "Principles of banking, insurance, and financial markets", "Investment; commercial, retail, and central banks", "Financial instruments: shares, bonds, futures and derivatives").

\section{Findings}

It is vital to note that ICT diversifies significantly the process of mastering foreign vocabulary and enriches totally the content of the didactic principles as the starting point of the organization of the educational process. Effective use of computer programs and capabilities of modern means of communication allows you to perform lexical, semantic exercises, tests, receive advice from teachers, and future employers, share experiences with peers, foreign speakers from around the world, do independent researches, prepare presentations, projects, etc. [9, p. 34].

"Social media was not only useful for communicating with others but also learning English" (after Alnujaidi' experiment results (2017), where 103 university-level English learners within Saudi Arabia's higher education system were asked) [14].

Thus, we considered the state policy on mastering the English language in the Ukrainian High Schools is constructive. The most meaningful is teaching the professional disciplines in English as part of the Ukrainianlanguage program (English as Medium of Instruction for Ukrainians EMI-u).

According to development of the information society, the main product of which is information and knowledge, as well as unimpeded communication within and outside any occupation, where the dominant language of communication is English, we created a training course "English for Bachelors in Finance: Bilingual Education" for 2nd year bachelor students in Finance, Banking and Insurance. The aim was to improve basic methods and techniques of teaching, educational activities in the digital society, 
increasing the mobility of applicants, organizing the educational process in formal and dual education.

Stress that as a part of the empirical phase of the study, an analytical and synthetic (affirmative) survey of 63 future bachelors in finance from Hlukhiv Agrotechnical Institute named after S.A. Kovpak and Sumy National Agrarian University (Sumy Region, Ukraine) have been conducted for two months (March-April) 2020. The survey was held with a parallel testing of the distance author's course. It covered the following areas:

- identifying the level of motivation in students to learn English (59.26\% respondents would like to get B2 level in professional English at the end of studying);

- determining the compliance of acquired abilities with the previous students' expectations (a result showed that only $27.61 \%$ of students determine their English level as a fluent speaker);

- finding out the level of satisfaction of students with cooperation with English teachers: effectiveness of methods, techniques, tools, etc. (31.42\% would prefer to use more ICT during the lesson; $41.36 \%$ noticed that they had needed more exercises for improving their professional vocabulary; only $27.22 \%$ respondents were satisfied with the lessons).

The study led to the conclusion that the general nature of digitalization of modern society projects new challenges and trends in the development of modern pedagogical science. A feature of the information society is the crucial role of ICT based on the principle of "knowledge society".

\section{Conclusions}

As a consequence we can safely assume that:

- the achievement of effective communication in real professional conditions encourages the provision of organizational and methodological principles for the formation of English lexical competence in future financiers as the ability of a specialist to use the language professionally oriented vocabulary effectively in the process of professional activity in terms of digitization of professional information;

- we have found that across information society demands the most effective general didactic principles for the formation of English lexical competence in future bachelors of finance are scientificity, consciousness, systematicity and consistency, visualization, continuity and perspective, 
connection between theory and practice, active interdisciplinary communication (coordination);

- the methodical principles (reliance on lexical rules, taking into account the rational coordination of algorithmic, semi-heuristic and heuristic learning actions during the acquisition of vocabulary) also play a significant role in such educational conditions;

- professional use of interactive types of education, ICT tools (emails, Google Presentations, Google Classroom, Zoom, Edmodo, Skype, Internet Browsers, Microsoft Office, Microsoft Excel, Microsoft Power Point, Trello, "A Dictionary of Finance and Banking Oxford Mobile App", Instagram, WhatsApp, Viber) allows to create an appropriate educational environment;

Our further investigations will concern a comprehensive study of the linguistic and methodological foundations of English lexical competence acquisition by future finance professionals according to the requirements of modern society, a presentation the results of pedagogical experiment, creating a manual "English for Bachelors in Finance: Bilingual Education".

\section{References:}

1. Al Fadda Hind, A. (2020). Determining How Social Media Affects Learning English: An Investigation of Mobile Applications Instagram and Snap Chat in TESOL Classroom. Arab World English Journal, 11(1), 3-11. doi: https://dx.doi.org/ 10.24093/awej/vol11no1.1

2. Bakum, Z. P. (2010). Ukraiinska mova iak inozemna : Linghvodydaktychni problemy [Ukrainian as a foreign language: Linguistic didactic problems]. Filologhichni studiii: Naukovyi visnyk Kryvorizkogho derzhavnogho pedaghoghichnogho universytetu [Philological Studies: Scientific Bulletin of Kryvyi Rih State Pedagogical University]: zb. nauk. prats. Vyp. 5. Kryvyi Righ: Vydavnychyi dim, pp. 226-232. (in Ukrainian)

3. Bakum, Z. P. (2019). Navchannia inozemnykh mov: kros-kulturnyi pidkhid [Learning foreign languages: a cross-cultural approach]: monoghrafiia/ Z. P. Bakum, O. O. Palchykova, S. S. Kostiuk. Ternopil: FOP Osadca Yu. V., 288 p. (in Ukrainian)

4. Bihych, O. B., Borysko, N. F., Boretska, H. E. ta in. (2013). Metodyka navchannya inozemnykh mov $i$ kultur: teoriia $i$ praktyka [Methods of teaching foreign languages and cultures: theory and practice]: pidruchnyk dlia stud. klasychnykh, pedahohichnykh i linhvistychnykh universytetiv / za zah. red. S. Yu. Nikolaievoii. Kyiv: "Lenvit", 590 p. (in Ukrainian)

5. Bykov, V. Yu. (2013). Informatsiyne suspilstvo i osvita. [Information society and education]. Pedahohichna maysternist akademika Ivana Zyazyuna. no. 1, pp. 39-50. Retrieved from: http://www.ime.edu-ua.net/el_lib.html (accessed 02 April 2020). (in Ukrainian) 
6. Common European Framework of Reference for Languages: learning, teaching, assessment (2011). Retrieved from: https://rm.coe.int/1680459f97 (accessed 05 May 2020).

7. Druker, P. (2004). Entsiklopediya menedzhmenta: Ves Piter Druker v odnoy knige: luchshie raboty po menedzhmentu, napisannye za 60 let [Encyclopedia of Management: All Peter Drucker in One Book: Best Management Works Written in 60 Years] / O.L. Pelyavskiy (per. s angl.). M., SPb.; K.: Izdatelskiy dom "Vilyams", 421 p. (in Russian)

8. Lightfoot, A. (2020). Using mobile apps to teach English remotely. Retrieved from: https://www.teachingenglish.org.uk/sites/teacheng/files/Teaching-withmobile-messenger-apps_FINAL.pdf (accessed 14 May 2020) (unpublished).

9. Makarenko, I. P. (2010). Formirovanie u studentov retseptivnikh leksichnikh navykov na osnove sistemy tekstov dlya chteniya [Formation of receptive lexical skills in students based on a system of texts for reading] (PhD Thesis), Minsk, 26 p. (in Russian)

10. Potiuk, I. Ye. (2014). Formuvannya anhlomovnoyi leksychnoyi kompetentsiyi u maybutnikh fakhivtsiv sfery turyzmu na zasadakh navchalnykh stratehiy [Formation of English lexical competence in future specialists in the field of tourism on the basis of educational strategies]. Naukovi zapysky. Seriia: pedagogika, no. 3, pp. 111-116. (in Ukrainian)

11.Semenchuk, Yu. A. (2017). Interaktivnoye obucheniye studentov angliyskoy ekonomicheskoy leksike [Interactive student training in English economic vocabulary]: monog. Under the scientific. ed. O. B. Tarnopolsky. Ternopil: Vector, 212 p. (in Russian)

12.Shandra, N. A. (2018). Etapy i vpravy dlya formuvannya anhlomovnoyi leksychnoyi kompetentnosti u profesiyno oriyentovanomu pysemnomu spilkuvanni maybutnikh fakhivtsiv z informatsiynykh tekhnolohiy [Stages and exercises for the formation of English lexical competence in professionally oriented written communication of future specialists in information technology]. Pedahohichni nauky: teoriya, istoriia, innovatsiini tekhnolohiii, vol. 10, no. 84, pp. 260-272. Retrieved from https://pedscience.sspu.sumy. ua/wp-content/uploads/2019/04/24-1.pdf (accessed 10 May 2020). (in Ukrainian)

13. Shchukin, A. N. (2004). Obuchenie inostrannym yazykam: Teoriya $i$ praktika [Teaching Foreign Languages: Theory and Practice]: Uch. pos. Moskva: Filomatis, 416 p. (in Russian)

14. Shveytser, A. D. (2009). Sovremennaya sotsiolingvistika: Teoriya, problemy, metody [Modern sociolinguistics: Theory, problems, methods]. Moskva: URSS [LIBROKOM], 176 p. (in Russian)

15. Smolina, S. V. (2010). Metodyka formuvannya inshomovnoyi leksychnoyi kometentnosti [Methodology of forming foreign lexical competence]. Inozemni movy, no. 4, pp. 16-23. (in Ukrainian)

16. UNESCO (2005). Towards Knowledge Societies. Paris. Retrieved from: http://www.unesco.org/new/en/communication-andinformation/resources/publications-and-communicationmaterials/publications/full-list/towards-knowledge-societies-unesco-worldreport/ (accessed 01 May 2020)

17. Vakulenko, M. O. (2015). Ukrayinska terminolohiia: kompleksnyi linhvistychnyi analiz [Ukrainian terminology: complex linguistic analyze]: monoghrafiia. Ivano-Frankivsk: Foliant, 315 p. (in Ukrainian) 